\title{
Oligomers, organosulfates, and nitrooxy organosulfates in rainwater identified by ultra-high resolution electrospray ionization FT-ICR mass spectrometry
}

\author{
K. E. Altieri ${ }^{1}$, B. J. Turpin ${ }^{2}$, and S. P. Seitzinger ${ }^{1,3}$ \\ ${ }^{1}$ Institute of Marine and Coastal Sciences, Rutgers University, New Brunswick, NJ, USA \\ ${ }^{2}$ Department of Environmental Sciences, Rutgers University, New Brunswick, NJ, USA \\ ${ }^{3}$ Rutgers/NOAA CMER Program, Rutgers University, New Brunswick, NJ, USA
}

Received: 14 August 2008 - Published in Atmos. Chem. Phys. Discuss.: 23 September 2008

Revised: 15 December 2008 - Accepted: 24 March 2009 - Published: 7 April 2009

\begin{abstract}
Wet deposition is an important removal mechanism for atmospheric organic matter, and a potentially important input for receiving ecosystems, yet less than $50 \%$ of rainwater organic matter is considered chemically characterized. Precipitation samples collected in New Jersey, USA, were analyzed by negative ion ultra-high resolution electrospray ionization Fourier transform ion cyclotron resonance mass spectrometry (FT-ICR MS). Elemental compositions of 552 unique molecular species were determined in the mass range $50-500 \mathrm{Da}$ in the rainwater. Four main groups of organic compounds were identified: compounds containing carbon, hydrogen, and oxygen (CHO) only, sulfur (S) containing CHOS compounds, nitrogen $(\mathrm{N})$ containing $\mathrm{CHON}$ compounds, and $\mathrm{S}$ - and $\mathrm{N}$ - containing CHONS compounds. Organic acids commonly identified in precipitation were detected in the rainwater. Within the four main groups of compounds detected in the rainwater, oligomers, organosulfates, and nitrooxy-organosulfates were assigned based on elemental formula comparisons. The majority of the compounds identified are products of atmospheric reactions and are known contributors to secondary organic aerosol (SOA) formed from gas phase, aerosol phase, and in-cloud reactions in the atmosphere. It is suggested that the large uncharacterized component of SOA is the main contributor to the large uncharacterized component of rainwater organic matter.
\end{abstract}

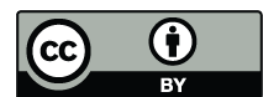

Correspondence to: K. E. Altieri (altieri@marine.rutgers.edu)

\section{Introduction}

Precipitation is an efficient removal mechanism for atmospheric organic matter, which is a mixture of organic compounds that can influence climate, air quality, and ecosystem health. Dissolved organic carbon (DOC) is a ubiquitous component of rainwater and can be higher in concentration than inorganic species such as nitric and sulfuric acids (Willey et al., 2000). Organic acids contribute significantly to rainwater acidity in urban areas (Kawamura et al., 1996; Pena et al., $2002)$, and can be the main contributor to acidity (80-90\%) in remote areas (Andreae et al., 1988). Thus, organic acids are frequently the focus of studies on rainwater DOC. However, the contribution of organic acids to total DOC ranges from only $14-36 \%$, with other known compound classes (e.g., aldehydes, amino acids) contributing $<10 \%$ to the total DOC (Avery et al., 2006). Approximately 50\% of rainwater dissolved organic matter (DOM) is considered uncharacterized at both the compound class and individual compound level (Willey et al., 2000). The complexity of rainwater DOM and the large percent considered uncharacterized has made it difficult to determine the role of rainwater DOM in regional and global carbon budgets (Raymond, 2005).

A large percentage of the uncharacterized rainwater DOM has been attributed to macromolecular organic matter like that found in atmospheric aerosols, fog water and cloud water (Zappoli et al., 1999; Krivacsy et al., 2000; Feng and Moller, 2004; Likens, 1983). Much of this macromolecular material has been termed humic like substances (HULIS) because of properties similar to terrestrial and aquatic humic and fulvic acids (Graber and Rudich, 2006). It is largely unknown how the HULIS fraction of atmospheric organic matter may

Published by Copernicus Publications on behalf of the European Geosciences Union. 
Table 1. Bulk properties of rainwater samples collected in New Jersey, USA.

\begin{tabular}{lccccccccc}
\hline Date Collected & Storm Trajectory & $\begin{array}{c}\text { Rainfall Amount } \\
(\mathrm{cm})\end{array}$ & $\begin{array}{c}\mathrm{Temp} \\
{ }^{\circ} \mathrm{C}\end{array}$ & $\mathrm{pH}$ & $\begin{array}{c}\mathrm{NO}_{3}^{-} \\
(\mu \mathrm{M})\end{array}$ & $\begin{array}{c}\mathrm{NH}_{4}^{+} \\
(\mu \mathrm{M})\end{array}$ & $\begin{array}{c}\mathrm{DON} \\
(\mu \mathrm{M})\end{array}$ & $\begin{array}{c}\mathrm{DOC} \\
(\mu \mathrm{M})\end{array}$ & $\begin{array}{c}\mathrm{PO}_{4}^{3-} \\
(\mu \mathrm{M})\end{array}$ \\
\hline $\begin{array}{l}\text { 14 May 2002 } \\
\begin{array}{l}\text { Camden } \\
\text { 5 October 2002 }\end{array}\end{array}$ & $\mathrm{SW}$ & 3.0 & 15 & 4.0 & 32 & 44 & 29 & 259 & 0.1 \\
$\begin{array}{l}\text { Camden } \\
\begin{array}{l}\text { 20 July 2002 } \\
\text { Pinelands }\end{array}\end{array}$ & $\mathrm{W}$ & 0.4 & 21 & 4.1 & 44 & 94 & 33 & 263 & 0.5 \\
\hline
\end{tabular}

affect aerosol properties, including the ability to nucleate cloud droplets, and the ability to absorb light. The complexity of HULIS in atmospheric waters (aerosol water, rainwater, and cloud water) poses a significant analytical challenge, and thus the sources of HULIS to the atmosphere are not well understood. Possibilities include primary terrestrial and marine sources, biomass burning, and secondary organic aerosol (SOA) formation mechanisms such as oligomerization (Graber and Rudich, 2006).

Significant progress has been made in identifying the composition of complex DOM in organic aerosols. Advances have been made using mass spectrometric methods such as electrospray ionization mass spectrometry (ESI-MS), matrix assisted laser desorption/ionizaton mass spectrometry (MALDI-MS), and aerosol mass spectrometry (Kalberer et al., 2004; Tolocka et al., 2004; Iinuma et al., 2007b; Gao et al., 2004a, b, 2006; Liggio et al., 2005). The advances are possible because high resolution mass spectrometry allows assignments of elemental compositions to all compounds detected in a sample (Marshall, 1995, 1997). For example, Fourier transform ion cyclotron resonance mass spectrometry (FT-ICR MS) can have sub ppm accuracy and resolution $>100000$ (Senko et al., 1996). These advanced mass spectrometry techniques have allowed the identification of oligomers formed through smog chamber and cloud water experiments (Altieri et al., 2008; Gao et al., 2004a, b, 2006; Kalberer et al., 2004), oligomers and fulvic acids in ambient aerosols (Reemtsma et al., 2006a, b), and organosulfates and nitrooxy organosulfates in smog chamber and ambient aerosols (Gomez-Gonzalez et al., 2008; Iinuma et al., 2007a; Romero and Oehme, 2005; Surratt et al., 2007, 2008). To our knowledge ultra-high resolution mass spectrometric techniques have not yet been applied to investigate the complex mixture of DOM in rainwater.

In this study ultra-high resolution electrospray ionization (ESI) FT-ICR MS is used to conduct a detailed analysis of the compound specific composition of precipitation in the mass range 50-500 Da collected in New Jersey, USA. Four main compound classes with both biogenic and anthropogenic sources were detected in the precipitation. Some compounds detected have distinct primary sources; however, the majority of these compounds are formed from secondary processes, and can be incorporated into rainwater either from cloud droplets directly, or from SOA formed through gas phase, aerosol phase, and in-cloud reactions.

\section{Sample collection and analysis}

\subsection{Sample collection}

Rainwater was collected from two sites in the northeastern USA. The urban site Camden, NJ (Latitude $39^{\circ} 56^{\prime} 57.45^{\prime \prime} \mathrm{N}$; Longitude $75^{\circ} 7^{\prime} 16.60^{\prime \prime} \mathrm{W}$; elevation $11 \mathrm{~m}$ ) is a city directly across the Delaware River from Philadelphia, PA and is in a heavily urbanized region. The rural site Pinelands, NJ is located 30 miles east of Camden in the Lebanon State Forest, though located in a forest it is impacted by urban airflow (Latitude $39^{\circ} 56^{\prime} 43.61^{\prime \prime} \mathrm{N}$; Longitude $74^{\circ} 37^{\prime} 1.52^{\prime \prime} \mathrm{W}$; elevation $1 \mathrm{~m}$ ). Two samples were collected from the Camden, NJ site, one collected in spring and one collected in fall. One sample was collected from the Pinelands, NJ site in summer (Table 1). The samples were collected using wet-dry deposition collectors (Aerochem Metrics Model 301, Bushnell, FL). The rain collectors were fitted with stainless steel buckets and opened only during wetfall events. The type of collector used and the placement of the collector at the site adhere to regulations outlined by the National Atmospheric Deposition Program (Bigelow et al., 2001). Samples were collected within $12 \mathrm{~h}$ of each rain event to minimize microbial degradation of DOM and consumption of inorganic nutrients. Sample temperature and $\mathrm{pH}$ were measured immediately after collection and samples were filtered through precombusted glass fiber filters (Whatman GFF; baked for four hours at $500^{\circ} \mathrm{C}$; then rinsed with deionized water) ensuring analysis of the dissolved constituents only. Contamination due to field sampling and laboratory sample processing was minimal (field and filter blanks $<5 \%$ DOC-C). Rainwater was stored at $-20^{\circ} \mathrm{C}$ in polypropylene screw-capped tubes until analysis. 


\subsection{Chemical analyses}

Bulk nutrients $\left(\mathrm{NO}_{3}^{-}+\mathrm{NO}_{2}^{-}, \mathrm{NH}_{4}^{+}, \mathrm{PO}_{4}^{3-}\right)$ were measured on the three rain samples with an automated nutrient analyzer and standard colorimetric methods (Lachat, Inc). DOC was measured by high-temperature catalytic oxidation with a Shimadzu Total Organic Carbon (TOC) 5000A analyzer (Sharp et al., 1993). Dissolved organic nitrogen was determined as the difference between total dissolved nitrogen measured with an Antek 7000 TN Analyzer (Seitzinger and Sanders, 1999) and dissolved inorganic nitrogen $\left(\mathrm{NO}_{3}^{-}+\mathrm{NO}_{2}^{-}\right.$, and $\mathrm{NH}_{4}^{+}$). Calibrations were performed using potassium hydrogen phthalate standards for DOC and urea and nitrate standards for TDN.

\subsection{Ultra-high resolution electrospray ionization FT-ICR MS}

Analyses were performed on the three rainwater samples with a 7-T Fourier transform ion cyclotron resonance mass spectrometer equipped with an ESI source (FT-ICR MS) and operated in the negative ion mode. The sample was diluted with methanol 50:50 v/v immediately before injection to limit solvent interaction. The sample was introduced into the ESI source by direct infusion with a flow rate of $5 \mu \mathrm{L} \mathrm{min}^{-1}$. The needle voltage was $3.02 \mathrm{kV}$, the capillary voltage was $-9.44 \mathrm{~V}$, the capillary temperature was $260^{\circ} \mathrm{C}$, and the tube lens was $-57 \mathrm{~V}$. The spectra were mass calibrated with standard ions using an external calibrant (G2421A Agilent "tuning mix") and the residual root mean square error after calibration was 1.1-1.6 ppm. The mass lists were processed and exported using Xcalibur v2.0 SR2 (ThermoFisher Scientific).

Midas Formula Calculator Software (v1.1) was used to calculate all mathematically possible formulas for all ions with a signal to noise ratio $\geq 10$ using a mass tolerance of $\pm 1 \mathrm{ppm}$. An unlimited number of ${ }^{12} \mathrm{C}$ and ${ }^{1} \mathrm{H}$, up to fifteen ${ }^{14} \mathrm{~N}$ and ${ }^{16} \mathrm{O}$, and one of each ${ }^{32} \mathrm{~S}$ and ${ }^{31} \mathrm{P}$ were allowed in the molecular formula calculations. The average mass error for all assignments was $0.3 \mathrm{ppm}$. Boundary values for molecular elemental ratios were applied as a filtering tool (Koch et al., 2005). The $\mathrm{O}: \mathrm{C}, \mathrm{H}: \mathrm{C}$, and $\mathrm{N}: \mathrm{C}$ ratios were limited to $<5, \geq 0.3$, and $<2$ respectively. Ions were also characterized by the number of rings plus double bonds (i.e., double bond equivalents (DBE)), calculated from Eq. (1) (McLafferty, 1993):

$$
\mathrm{DBE}=c-\frac{1}{2} h+\frac{1}{2}(n+p)+1
$$

for elemental composition, $\mathrm{C}_{c} \mathrm{H}_{h} \mathrm{O}_{\mathrm{o}} \mathrm{N}_{\mathrm{n}} \mathrm{P}_{\mathrm{p}} \mathrm{S}_{\mathrm{s}}$

\section{Sample comparison}

Though the three rainwater samples analyzed were from different locations and seasons, the storm trajectories and bulk properties of the samples are similar (Table 1) and fall within
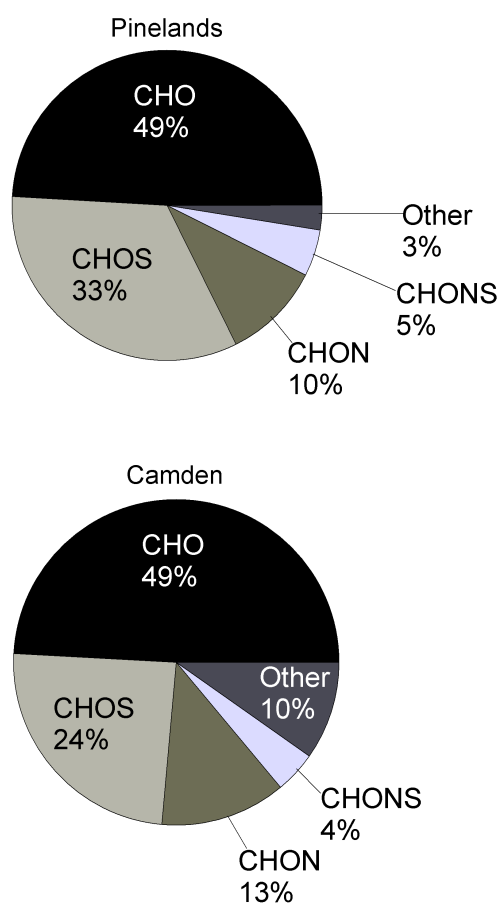

Fig. 1. Comparison of the number of each type of elemental formula present (negative ion mode) in precipitation samples. There were 388 total masses detected in the Pinelands sample collected on the 20 July 2002 and 383 total masses detected in the Camden sample collected on the 5 October 2002.

the ranges reported for continental precipitation (Seitzinger et al., 2003; Willey et al., 2000). The composition of the DOM in all three samples was also very similar, as discussed below. In the Camden spring sample, there were 161 masses detected in the mass range of 50-300 Da. However, only $13 \%$ of them were unique to that sample, i.e., $87 \%$ of the masses detected appeared in one or both of the other samples. Though the Pinelands sample was analyzed over a slightly smaller mass range (50-400 Da) than the fall Camden sample (50-500 Da), the samples are similar in the total number of masses detected, 388 and 383, respectively. Of the 388 masses detected in the Pinelands sample, $64 \%$ were detected in one of the other two samples (i.e., $36 \%$ are unique). For the fall Camden sample, $84 \%$ of the masses were detected in one of the other two samples (i.e., 16\% are unique).

The masses detected fall into four main compound classes: carbon, hydrogen and oxygen only (CHO), sulfur (S) containing CHOS compounds, nitrogen $(\mathrm{N})$ containing $\mathrm{CHON}$ compounds, and $\mathrm{S}-$ and $\mathrm{N}$ - containing CHONS compounds. The number of compounds in each compound class was very similar in both the Camden fall and Pinelands summer samples (Fig. 1). Approximately $50 \%$ of the compounds in the negative ion mode are composed only of CHO. Approximately $25-30 \%$ of the compounds are composed of CHOS, and $\sim 5 \%$ are composed of CHONS. The remaining $10-25 \%$ 

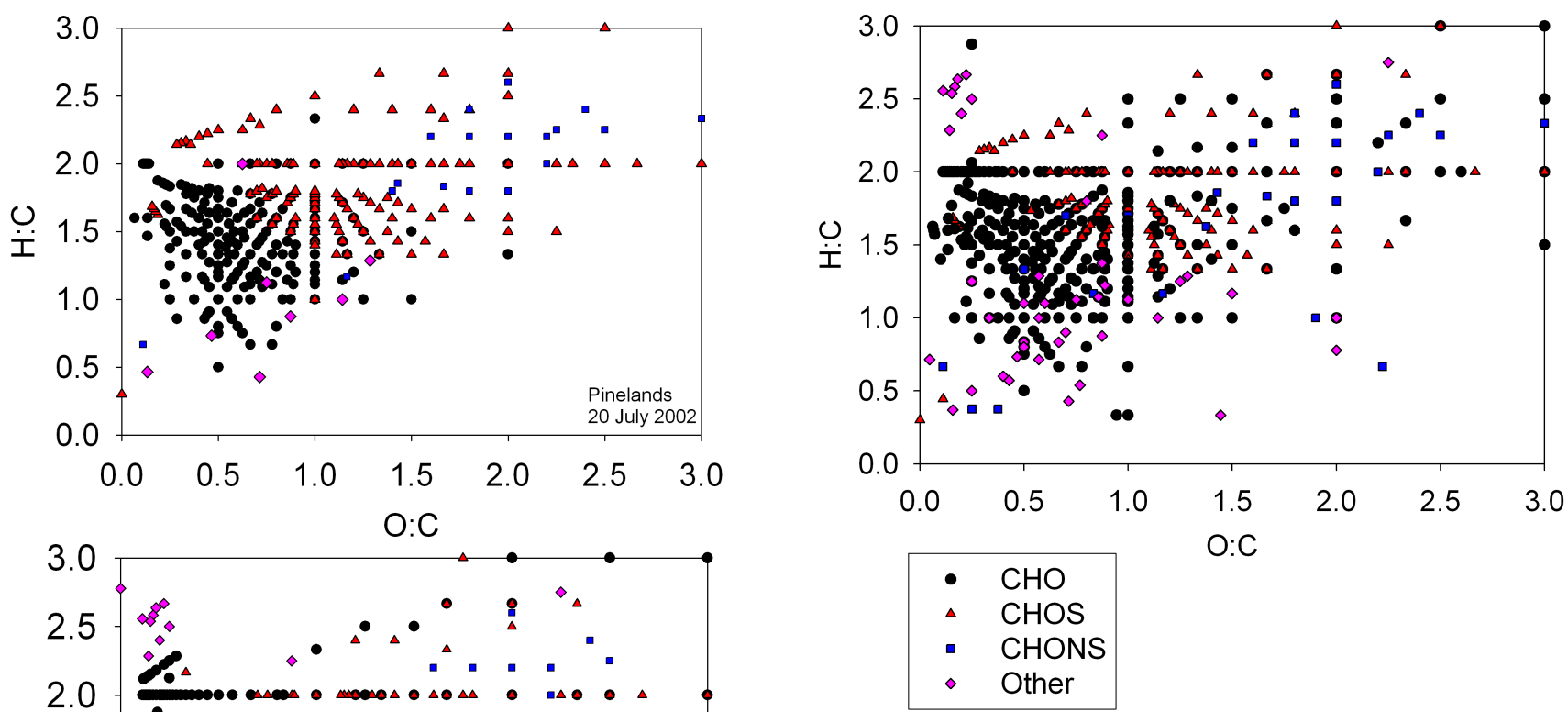

Fig. 3. Van Krevelen plot of the combined precipitation samples FT-ICR MS negative ion mode $m / z 50$ to 500 (color figure).

In the analysis that follows (e.g., Fig. 3, Table 2), we have combined the elemental formulas for each of the three samples due to the high percentage of overlap in the types of elemental formulas (i.e., compound class; Fig. 1) the similarities in number and type of elemental formulas (Fig. 2), and the small number of samples. Thus we will consider this combined data representative of a precipitation sample collected from an urban impacted (i.e., downwind of a major city) location in New Jersey, USA. As an example, all of the negative ion elemental formulas determined in the 20 July 2002 sample are listed with their corresponding $\mathrm{m} / \mathrm{z}$ (Supplemental Information: http://www.atmos-chem-phys.net/9/ 2533/2009/acp-9-2533-2009-supplement.pdf).

of the elemental formulas includes CHON compounds and compounds with phosphorous $(\mathrm{P})$ in the elemental formula; those compounds will be discussed in a future manuscript Altieri et al. (2009). This analysis is based solely on negative ion FT-ICR MS, and as such focuses only on compounds that can be detected in the negative ion mode (e.g., carboxylic acids). It should be noted that for each elemental composition assigned based on the measured mass, multiple structural isomers are possible, and thus the reported total number of compounds is likely an underestimate. The van Krevelen diagrams, which plot the hydrogen to carbon $(\mathrm{H}: \mathrm{C})$ ratio as a function of the oxygen to carbon $(\mathrm{O}: \mathrm{C})$ ratio for each compound, can be used to display compositional characteristics and to compare the elemental ratios of each compound in a sample (Wu et al., 2004). As evident in the van Krevelen diagrams, the elemental ratios of the compounds in each group (i.e., CHO, CHOS, CHONS) are also similar in both the Camden and Pinelands samples (Fig. 2).

\section{Organic acids and oligomers}

Eight organic acids identified in the rainwater based on their elemental formulas have been previously detected in precipitation samples: glyoxylic, glycolic, pyruvic, oxalic, lactic, malonic, and succinic acids (Kieber et al., 2002). Formic acid is commonly detected in precipitation, but has a molecular weight less than the lower mass detection limit of the FT-ICR MS $m / z 50$; therefore, although it is likely present in the samples, it is not detectable.

The potential sources of these eight organic acids include primary anthropogenic and biogenic emissions, as well as secondary formation from biogenic and anthropogenic precursors in the atmosphere (Kawamura et al., 2001, 2003; Sorooshian et al., 2007). Though there are primary emissions of organic acids, atmospheric aqueous phase reactions in clouds and aerosols have been hypothesized to be 
Table 2. The number of masses in each compound class and the average (arithmetic mean) elemental ratios for each compound class. The compounds contributing to the "other" category are listed below the darkened line.

\begin{tabular}{lccccccc}
\hline Type & \# of compounds & \% of Total & H:C & O:C & N:C & MW & OM:OC \\
\hline CHO & 262 & 48 & $1.5 \pm 0.4$ & $0.7 \pm 0.5$ & - & $193 \pm 58$ & $2.1 \pm 0.7$ \\
CHOS & 139 & 25 & $1.9 \pm 0.5$ & $1.3 \pm 0.8$ & - & $246 \pm 54$ & $3.4 \pm 1.5$ \\
CHONS & 28 & 5 & $1.8 \pm 0.6$ & $1.7 \pm 0.9$ & $2.7 \pm 1.9$ & $271 \pm 60$ & $4.2 \pm 1.5$ \\
CHON & 74 & 13 & $1.9 \pm 0.8$ & $1.6 \pm 1.4$ & $2.6 \pm 2.4$ & $192 \pm 68$ & $3.7 \pm 2.2$ \\
Other & 49 & 9 & $1.5 \pm 1$ & $1.0 \pm 1.1$ & $5.4 \pm 3.9$ & $272 \pm 80$ & $3.4 \pm 1.9$ \\
\hline CHONP & 29 & 5 & & & & & \\
CHONSP & 8 & 2 & & & & & \\
CHOP & 7 & 1 & & & & & \\
CHOSP & 5 & 1 & & & & & \\
\hline
\end{tabular}

Table 3. Organic acids and oligomers detected in the rainwater by negative ion FT-ICR MS. Compound identification based on comparison with FT-ICR MS negative ion data from methylglyoxal $+\cdot \mathrm{OH}$ oligomer series as described in (Altieri et al., 2008). Compounds from all 9 methylglyoxal oligomer series are represented. $n=1$ and $n=2$ indicates the addition of one and two hydroxy acids $\left(+\mathrm{C}_{3} \mathrm{H}_{4} \mathrm{O}_{2}\right)$ through esterification, respectively.

\begin{tabular}{lcccccc}
\hline Parent & \multicolumn{5}{c}{ Oligomers $n=1$} \\
\hline & $m / z^{-}$ & Elemental Formula & $m / z^{-}$ & Elemental Formula & $m / z^{-}$ & Elemental Formula \\
\hline Glyoxylic acid & 72.9931 & $\mathrm{C}_{2} \mathrm{H}_{1} \mathrm{O}_{3}$ & 145.01426 & $\mathrm{C}_{5} \mathrm{H}_{5} \mathrm{O}_{5}$ & 217.03546 & $\mathrm{C}_{8} \mathrm{H}_{9} \mathrm{O}_{7}$ \\
Glycolic acid & 75.00875 & $\mathrm{C}_{2} \mathrm{H}_{3} \mathrm{O}_{3}$ & 147.02991 & $\mathrm{C}_{5} \mathrm{H}_{7} \mathrm{O}_{5}$ & 219.05107 & $\mathrm{C}_{8} \mathrm{H}_{11} \mathrm{O}_{7}$ \\
Pyruvic acid & 87.0087 & $\mathrm{C}_{3} \mathrm{H}_{3} \mathrm{O}_{3}$ & 159.0299 & $\mathrm{C}_{6} \mathrm{H}_{7} \mathrm{O}_{5}$ & 231.05109 & $\mathrm{C}_{9} \mathrm{H}_{11} \mathrm{O}_{7}$ \\
Oxalic acid & 88.98796 & $\mathrm{C}_{2} \mathrm{H}_{1} \mathrm{O}_{4}$ & 161.00922 & $\mathrm{C}_{5} \mathrm{H}_{5} \mathrm{O}_{6}$ & 233.03034 & $\mathrm{C}_{8} \mathrm{H}_{9} \mathrm{O}_{8}$ \\
Succinic acid & 117.01935 & $\mathrm{C}_{4} \mathrm{H}_{5} \mathrm{O}_{4}$ & 189.04032 & $\mathrm{C}_{7} \mathrm{H}_{9} \mathrm{O}_{6}$ & 261.06157 & $\mathrm{C}_{10} \mathrm{H}_{13} \mathrm{O}_{8}$ \\
$m / z 131$ & 131.03501 & $\mathrm{C}_{5} \mathrm{H}_{7} \mathrm{O}_{4}$ & 203.0562 & $\mathrm{C}_{8} \mathrm{H}_{11} \mathrm{O}_{6}$ & 275.07719 & $\mathrm{C}_{11} \mathrm{H}_{15} \mathrm{O}_{8}$ \\
Malonic acid & 103.00358 & $\mathrm{C}_{3} \mathrm{H}_{3} \mathrm{O}_{4}$ & 175.02483 & $\mathrm{C}_{6} \mathrm{H}_{7} \mathrm{O}_{6}$ & 247.04596 & $\mathrm{C}_{9} \mathrm{H}_{11} \mathrm{O}_{8}$ \\
Malic acid & 133.01427 & $\mathrm{C}_{4} \mathrm{H}_{5} \mathrm{O}_{5}$ & 205.03546 & $\mathrm{C}_{7} \mathrm{H}_{9} \mathrm{O}_{7}$ & 277.05647 & $\mathrm{C}_{10} \mathrm{H}_{13} \mathrm{O}_{9}$ \\
$m / z 177$ & 177.04047 & $\mathrm{C}_{6} \mathrm{H}_{9} \mathrm{O}_{6}$ & 249.0616 & $\mathrm{C}_{9} \mathrm{H}_{13} \mathrm{O}_{8}$ & & \\
\hline
\end{tabular}

the predominant formation pathway of these organic acids (Blando and Turpin, 2000). Similarly, the atmospheric concentrations of these organic acids can only be supported by a substantial secondary formation mechanism (Sorooshian et al., 2007). Thus, the organic acids detected in the rainwater are likely predominantly from secondary atmospheric processes and incorporated during in-cloud or below-cloud scavenging.

In addition to the eight identified organic acids, there were an additional $254 \mathrm{CHO}$ compounds detected, representing $48 \%$ of the total compounds in the mass range 50-500 Da. The average (arithmetic mean) organic molecular weight to organic carbon weight (OM:OC) ratio for the $\mathrm{CHO}$ compounds in the mass range $50-500 \mathrm{Da}$ was $2.1 \pm 0.7$, the average $\mathrm{H}: \mathrm{C}$ and $\mathrm{O}: \mathrm{C}$ ratios were $1.5 \pm 0.4$ and $0.7 \pm 0.5$, respectively (Table 2). The elemental ratios for the $\mathrm{CHO}$ compounds are lower than typical organic acid ratios (OM:OC 2.5-3.8), and are more consistent with measured ratios for smog chamber generated oligomers, oligomers formed through cloud processing, aged atmospheric aerosol, and HULIS, all contributors to SOA (El-Zanan et al., 2005; Kiss et al., 2002; Kalberer et al., 2004; Altieri et al., 2008; Polidori et al., 2008).

The elemental formulas of the $\mathrm{CHO}$ compounds in the rainwater were compared to the elemental formulas of oligomers known to form through cloud processing reactions of methylglyoxal (Altieri et al., 2008); methylglyoxal is a water soluble compound with both biogenic and anthropogenic sources. The organic acids known to form through cloud processing of methylglyoxal were all detected in the rainwater, i.e., glyoxylic, glycolic, pyruvic, oxalic, succinic, malonic, and malic acids (Table 3 ). The methylglyoxal aqueous oligomerization scheme involves acid- or radical- catalyzed esterification of the organic acids with a hydroxy acid, e.g., lactic acid, leading to series of oligomers related by regular mass differences of $72.02113 \mathrm{Da}\left(\Delta \mathrm{C}_{3} \mathrm{H}_{4} \mathrm{O}_{2}\right.$; $\mathrm{Al}-$ tieri et al., 2008). All nine oligomer series present in the methylglyoxal cloud processing scheme were detected in the 


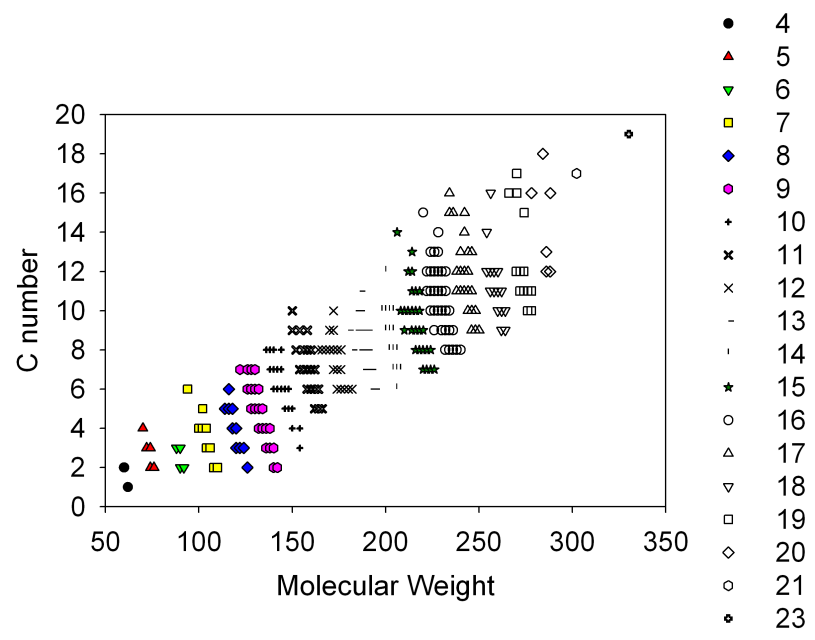

Fig. 4. Number of carbons per molecule versus the molecular weight of the molecule for compounds containing only $\mathrm{CHO}$ detected in the negative ion mode. Molecules with the same number of carbon and oxygen are marked by the same symbol and denoted as one "island". The island number in the legend corresponds to the sum of carbon and oxygen (color figure).

rainwater based on elemental formula comparisons (Table 3). For each organic acid detected, compounds containing elemental formulas consistent with the addition of one and two hydroxy acids through esterification were detected. For example, moving from left to right in Table 3 , glyoxylic acid $\left(\mathrm{C}_{2} \mathrm{H}_{1} \mathrm{O}_{3}\right)$, glyoxylic acid plus one addition of hydroxy acid through esterification $\left(\mathrm{C}_{5} \mathrm{H}_{5} \mathrm{O}_{5}\right)$, and glyoxylic acid plus two additions of hydroxy acid through esterification $\left(\mathrm{C}_{8} \mathrm{H}_{9} \mathrm{O}_{7}\right)$ were all detected. In addition to the elemental formulas being consistent with methylglyoxal oligomers, some of these elemental formulas are also consistent with compounds formed from photooxidation of other biogenic precursors such as $\alpha$ pinene oxidation leading to hydroxy glutaric acids (Claeys et al., 2007), highlighting that multiple structural isomers of each elemental formula are possible. Without further liquid chromatography or MS-MS analysis, it is not possible to discern the exact structure of these higher molecular weight compounds. Compounds with the same elemental formulas and patterns as reported here in the rainwater were also detected in the high molecular weight fraction $(\geq m / z 223)$ of aerosol derived water soluble organic carbon (Wozniak et al., 2008).

There are $\mathrm{CHO}$ compounds detected in the rainwater sample that are not part of the methylglyoxal oligomer series, but also have regular mass differences indicative of oligomers and/or HULIS (Figs. 3, 4). In addition to the van Krevelen (Fig. 3), another way to visualize compounds related by regular mass differences is an island plot (Reemtsma et al., 2006a), which plots the number of carbon atoms of each molecule against the molecular weight of the molecule. When the sum of the number of carbons and oxygens for a set of compounds is the same, those compounds group as "islands" in the plot (denoted by different markers; Fig. 4). There were 19 islands detected in the mass range 50-500 Da for the compounds containing only $\mathrm{CHO}$, and the sum of carbon and oxygen ranged from 4-23.

In each island the elemental composition changes in a systematic way from one molecule to the next. Moving horizontally within an island increases the saturation of a molecule $(+2 \mathrm{H})$. Moving horizontally from one island to another introduces additional oxygen $(+1 \mathrm{O})$. Moving vertically within an island changes the composition by exchanging one oxygen atom for $\mathrm{CH}_{4}$, hence the island number $(\# \mathrm{C}+\# \mathrm{O})$ remains unchanged. These clustered island patterns in the rainwater are typical of fulvic acid isolates from natural organic matter samples (Reemtsma et al., 2006a; Stenson et al., 2003), and fulvic acids and oligomers detected in water soluble aerosols (Reemtsma et al., 2006b), indicating the presence of oligomeric compounds and HULIS in the complex rainwater DOM.

\section{Sulfur compounds}

\subsection{Organosulfates}

There were 139 CHOS compounds detected (50-500 Da), representing $25 \%$ of the total compounds (Table 2). The average molecular weight and average OM:OC ratio of the CHOS compounds were higher than the CHO compounds, which is consistent with the addition of a sulfur atom onto the molecule. The number of double bond equivalents (DBEs) calculated from the CHOS elemental formulas indicates that they are likely aliphatic compounds (average $\mathrm{DBE}<3$ ). The average $\mathrm{H}: \mathrm{C}$ and $\mathrm{O}: \mathrm{C}$ ratios for the $\mathrm{CHOS}$ compounds were also higher than the elemental ratios of the $\mathrm{CHO}$ compounds. The CHOS compounds (red triangles, Fig. 3) group to the right, and higher, on the van Krevelen diagram than the $\mathrm{CHO}$ compounds (black circles), indicating a higher degree of oxidation. This placement on the van Krevelen, and the higher $\mathrm{H}: \mathrm{C}$ and $\mathrm{O}: \mathrm{C}$ ratios, are consistent with the addition of the sulfur as a sulfate $\left(\mathrm{SO}_{4}^{2-}\right)$ group. Sulfate was detected in all of the samples at $m / z 96.960103$, and organosulfates, if present, are also expected to be seen in the negative ion mode (Surratt et al., 2008 and refs within). There were 134 CHOS compounds with oxygen to sulfur (O:S) ratios of 4-11, which allows all 134 compounds to potentially have sulfate functionalities. The high O:S ratios and the high degree of oxidation in the molecular formulas indicates that the bulk of the negative ion CHOS compounds detected in the rainwater samples are likely organosulfates.

Of the 134 CHOS compounds detected with O:S ratios $>4,28$ have elemental formulas consistent with organosulfate esters detected in ambient SOA, and demonstrated to form in laboratory smog chamber experiments (Surratt et al., 2008; Romero and Oehme, 2005; Reemtsma et al., 2006b). These organosulfate esters are formed in the presence of high 
Table 4. Organosulfate compounds detected in the rainwater by negative ion FT-ICR MS. These elemental formulas were also reported in (Surratt et al., 2008) as organosulfates formed when biogenic precursor VOC's are oxidized with high acidity sulfate seed aerosols.

\begin{tabular}{|c|c|c|c|c|c|c|c|}
\hline \multicolumn{2}{|c|}{ Isoprene } & \multicolumn{2}{|c|}{$\alpha$-pinene } & \multicolumn{2}{|c|}{ Limonene } & \multicolumn{2}{|c|}{$\alpha$-terpinene } \\
\hline$m / z^{-}$ & Elemental Formula & $m / z^{-}$ & Elemental Formula & $m / z^{-}$ & Elemental Formula & $m / z^{-}$ & Elemental Formula \\
\hline 138.970667 & $\mathrm{C}_{2} \mathrm{H}_{3} \mathrm{O}_{5} \mathrm{~S}$ & 223.028182 & $\mathrm{C}_{7} \mathrm{H}_{11} \mathrm{O}_{6} \mathrm{~S}$ & 239.023097 & $\mathrm{C}_{7} \mathrm{H}_{11} \mathrm{O}_{7} \mathrm{~S}$ & 253.038747 & $\mathrm{C}_{8} \mathrm{H}_{13} \mathrm{O}_{7} \mathrm{~S}$ \\
\hline 152.986318 & $\mathrm{C}_{3} \mathrm{H}_{5} \mathrm{O}_{5} \mathrm{~S}$ & 226.986711 & $\mathrm{C}_{5} \mathrm{H}_{7} \mathrm{O}_{8} \mathrm{~S}$ & 251.059482 & $\mathrm{C}_{9} \mathrm{H}_{15} \mathrm{O}_{6} \mathrm{~S}$ & 279.054397 & $\mathrm{C}_{10} \mathrm{H}_{15} \mathrm{O}_{7} \mathrm{~S}$ \\
\hline 154.965582 & $\mathrm{C}_{2} \mathrm{H}_{3} \mathrm{O}_{6} \mathrm{~S}$ & 237.043832 & $\mathrm{C}_{8} \mathrm{H}_{13} \mathrm{O}_{6} \mathrm{~S}$ & 267.054397 & $\mathrm{C}_{9} \mathrm{H}_{15} \mathrm{O}_{7} \mathrm{~S}$ & 281.070047 & $\mathrm{C}_{10} \mathrm{H}_{17} \mathrm{O}_{7} \mathrm{~S}$ \\
\hline 168.981232 & $\mathrm{C}_{3} \mathrm{H}_{5} \mathrm{O}_{6} \mathrm{~S}$ & 279.054397 & $\mathrm{C}_{10} \mathrm{H}_{15} \mathrm{O}_{7} \mathrm{~S}$ & 279.054397 & $\mathrm{C}_{10} \mathrm{H}_{15} \mathrm{O}_{7} \mathrm{~S}$ & 283.049312 & $\mathrm{C}_{9} \mathrm{H}_{15} \mathrm{O}_{8} \mathrm{~S}$ \\
\hline 210.991797 & $\mathrm{C}_{5} \mathrm{H}_{7} \mathrm{O}_{7} \mathrm{~S}$ & 281.070047 & $\mathrm{C}_{10} \mathrm{H}_{17} \mathrm{O}_{7} \mathrm{~S}$ & 281.070047 & $\mathrm{C}_{10} \mathrm{H}_{17} \mathrm{O}_{7} \mathrm{~S}$ & 283.085697 & $\mathrm{C}_{10} \mathrm{H}_{19} \mathrm{O}_{7} \mathrm{~S}$ \\
\hline 213.007447 & $\mathrm{C}_{5} \mathrm{H}_{9} \mathrm{O}_{7} \mathrm{~S}$ & 297.064962 & $\mathrm{C}_{10} \mathrm{H}_{17} \mathrm{O}_{8} \mathrm{~S}$ & & & 297.064962 & $\mathrm{C}_{10} \mathrm{H}_{17} \mathrm{O}_{8} \mathrm{~S}$ \\
\hline 215.023097 & $\mathrm{C}_{5} \mathrm{H}_{11} \mathrm{O}_{7} \mathrm{~S}$ & & & & & & \\
\hline
\end{tabular}

Table 5. Nitrooxy organosulfate compounds detected in rainwater by negative ion FT-ICR MS. These same elemental formulas were also reported by (Surratt et al., 2008) and are formed when parent biogenic VOC's undergo reactions with high acidity sulfate seed aerosols with intermediate to high $\mathrm{NO}_{\mathrm{x}}$ levels. ${ }^{\mathrm{a}}$ The same nitrooxy organosulfates are also formed during $\alpha$-terpinene, $\gamma$-terpinene, and $\beta$-pinene oxidation (Surratt et al., 2008).

\begin{tabular}{cccccc}
\hline \multicolumn{2}{c}{ Isoprene } & \multicolumn{2}{c}{$\alpha$-pinene $^{\mathrm{a}}$} & \multicolumn{2}{c}{ Monoterpene } \\
\hline$m / z^{-}$ & Elemental Formula & $m / z^{-}$ & Elemental Formula & $m / z^{-}$ & Elemental Formula \\
\hline 244.013261 & $\mathrm{C}_{5} \mathrm{H}_{10} \mathrm{~N}_{1} \mathrm{O}_{8} \mathrm{~S}_{1}$ & 294.065296 & $\mathrm{C}_{10} \mathrm{H}_{16} \mathrm{~N}_{1} \mathrm{O}_{7} \mathrm{~S}_{1}$ & 342.05004 & $\mathrm{C}_{10} \mathrm{H}_{16} \mathrm{~N}_{1} \mathrm{O}_{10} \mathrm{~S}_{1}$ \\
260.008175 & $\mathrm{C}_{5} \mathrm{H}_{10} \mathrm{~N}_{1} \mathrm{O}_{9} \mathrm{~S}_{1}$ & & & \\
304.993253 & $\mathrm{C}_{5} \mathrm{H}_{9} \mathrm{~N}_{2} \mathrm{O}_{11} \mathrm{~S}_{1}$ & & & \\
\hline
\end{tabular}

acidity sulfate seed aerosols during particle phase and aqueous phase reactions of biogenic VOCs and their oxidation products (Surratt et al., 2008). Organosulfates formed from the gas phase oxidation of isoprene, $\alpha$-pinene, $\beta$-pinene, limonene, $\alpha$-terpinene, and $\gamma$-terpinene were all detected in the rainwater (Table 4).

\subsection{Nitrooxy-organosulfates}

There were 28 CHONS compounds detected (50-500 Da), representing $5 \%$ of the total compounds. The CHONS compounds had an average $\mathrm{H}: \mathrm{C}$ ratio similar to the $\mathrm{CHOS}$ compounds, but slightly higher O:C and OM:OC ratios (Table 2). The CHONS compounds have elemental formulas with higher oxygen content than the organosulfates and cluster even further to the right and above the $\mathrm{CHO}$ and CHOS compounds in the van Krevelen diagram (blue squares; Fig. 3) indicating an even higher degree of oxidation. The location of the CHONS compounds on the van Krevelen diagram, and the higher O:C ratios indicate that the nitrogen on the molecule is most likely an organic nitrate $\left(\mathrm{ONO}_{2}\right)$ functionality.

Five of the CHONS compounds have elemental formulas consistent with nitrooxy organosulfates detected in ambient aerosols and formed during laboratory smog chamber experiments (Table 5) conducted with high acidity sulfate seed aerosols and high $\mathrm{NO}_{\mathrm{x}}$ conditions (Surratt et al., 2007,
2008). Of the 23 remaining CHONS compounds, 18 have enough oxygen in their elemental formula for both a sulfate and nitrate functionality to be present $(\geq 7 \mathrm{O})$ suggesting those compounds are also nitrooxy organosulfates formed from other biogenic and anthropogenic VOC precursors.

\subsection{Sulfonates}

Four of the CHOS compounds have an O:S ratio too low to be sulfate functionalities $(<3)$, a high $\mathrm{C}$ content, and differ only by $\mathrm{CH}_{2}$ units $\left(\mathrm{C}_{16} \mathrm{H}_{25} \mathrm{O}_{3} \mathrm{~S}, \mathrm{C}_{17} \mathrm{H}_{27} \mathrm{O}_{3} \mathrm{~S}, \mathrm{C}_{18} \mathrm{H}_{29} \mathrm{O}_{3} \mathrm{~S}\right.$, and $\mathrm{C}_{19} \mathrm{H}_{31} \mathrm{O}_{3} \mathrm{~S}$ ). The elemental formulas of these four compounds are consistent with a class of persistent pollutants known as linear alkylbenzene sulfonates (LAS). The LAS compounds are used as synthetic surfactants and are surface active ingredients in detergents, shampoos, other cleaning compounds, and personal care products (Debelius et al., 2008; Lara-Martín et al., 2006). LAS compounds are toxic to a variety of organisms (Debelius et al., 2008) and as such are targeted in wastewater treatment plants (Reemtsma, 2003). Due to their widespread use, LAS compounds have been detected at various concentrations in river water, seawater and sediments (González-Mazo and Gómez-Parra, 1996; González-Mazo et al., 2002). To our knowledge, this is the first evidence that LAS compounds can occur in atmospheric samples of any kind, and their presence in the atmosphere is difficult to explain. If the LAS compounds were able to reach 
the atmosphere, the potential for negative impacts on receiving ecosystems would be extended due to the possibility of long transport times in the atmosphere before deposition.

\section{Atmospheric implications}

A number of lines of evidence suggest that the majority of compounds detected in these rainwater samples are from secondary processing in the atmosphere, and not primary emissions. First, the similarity in the number and types of compounds detected in the three rainwater samples from different seasons and locations in New Jersey is consistent with the organic matter being primarily from secondary processing in the atmosphere, and not local primary emissions. Second, the organic acids detected in the rainwater are likely predominantly formed through secondary processing reactions in the atmosphere, including in-cloud processing. In contrast, the sulfonates are likely primary anthropogenic compounds, and are pollutants known to be toxic to aquatic ecosystems; though the sulfonates are only four compounds out of the 552 total compounds detected. The majority of the compounds detected by negative ion FT-ICR MS in the rainwater have secondary sources both anthropogenic (e.g., organosulfates and nitrooxy organosulfates) and biogenic (e.g., oligomers from cloud processing of methylglyoxal).

Organosulfates likely contribute to the large percentage of uncharacterized water soluble organic carbon in atmospheric organic matter and could have been missed until recently because single derivatization protocols are likely to cause degradation or misinterpretation of these compounds (Surratt et al., 2007). Several organosulfates detected in the rainwater could be used as tracers for SOA that was formed under highly acidic conditions. Interestingly, in a study of DOM recovered from ice cores collected in Russia, $21 \%$ of the ions detected had organic S present in a sample from 1950, compared to $12 \%$ in a sample from 1300 AD (Grannas et al., 2006). This is consistent with an anthropogenic source of organic $\mathrm{S}$ capable of being transported long distances in the atmosphere before deposition, supporting the use of organosulfates as anthropogenic tracer compounds.

The nitrooxy organosulfates detected in the rainwater have been seen in nighttime ambient aerosol samples, highlighting the importance of $\mathrm{NO}_{3}$ radical oxidation chemistry (Iinuma et al., 2007a, b) in their formation. In the Surratt et al. (2008) study, nitrooxy organosulfates were detected during both the nighttime oxidation and photooxidation experiments with acidic sulfate seed aerosol, and intermediate or high $\mathrm{NO}_{\mathrm{x}}$ conditions $(\sim 1 \mathrm{ppm})$. The nitrooxy organosulfates detected in the precipitation sample could also be used as tracers for SOA that was formed under high acidity and high $\mathrm{NO}_{\mathrm{x}}$ conditions.

The oligomers, organosulfates, and nitrooxy organosulfates detected in the rainwater could all contribute to the HULIS fraction of atmospheric organic matter (Graber and
Rudich, 2006; Romero and Oehme, 2005). If the aqueous oligomerization of one water soluble organic compound (i.e., methylglyoxal) can account for 26 previously unidentified $\mathrm{CHO}$ compounds in the rainwater, it is possible that oligomerization of other known biogenic and anthropogenic precursor organic compounds through in-cloud or aerosolphase reactions may contribute substantially to the complex HULIS fraction measured in aqueous atmospheric organic matter, including rainwater. Previous studies have suggested that no one compound comprises more than a small percentage of the total DOC in rainwater. The large number of compounds detected (552 unique masses from $\mathrm{m} / \mathrm{z}, 50$ to 500), and the large contribution of multifunctional compounds (e.g., oligoesters, organosulfates, nitrooxy organosulfates) detected in the rainwater supports this idea. Unfortunately, quantification is not possible using ESI FT-ICR MS unless an authentic standard is used for each identified compound. Due to the large number of masses detected, and the lack of commercial availability of standards for these compounds, we were not able to quantify the mass contribution of each identified compound to total DOC concentration. However, as is typical for HULIS, the majority of these multifunctional compounds would not be separated and detected by traditional analytical techniques, highlighting the important advances made capable by ultra-high resolution mass spectrometry. This work provides motivation to expand studies of complex atmospheric organic matter to include quantitation, chromatographic separation and tandem MS-MS.

Acknowledgements. The authors acknowledge Melissa Soule, Elizabeth Kujawinski and the funding sources of the WHOI FT-MS Users' Facility (National Science Foundation OCE-0619608 and the Gordon and Betty Moore Foundation). Travel support for Katye E. Altieri to the WHOI FT-MS Facility was provided by the WHOI Director's discretionary funds. This research has been supported by grants from the US Department of Commerce's National Oceanic and Atmospheric Administration (NOAA) (NA07OAR4310279) and from the US Department of Agriculture Hatch Funds. Graduate student support for Katye E. Altieri was provided by the National Center for Environmental Research, US Environmental Protection Agency's Science to Achieve Results (STAR) Program R833751. Although the research described in this article has been funded in part by the United States Environmental Protection Agency, it has not been subjected to the Agency's required peer and policy review and therefore does not necessarily reflect the views of the Agency and no official endorsement should be inferred.

Edited by: A. Nenes 


\section{References}

Altieri, K. E., Seitzinger, S. P., Carlton, A. G., Turpin, B. J., Klein, G. C., and Marshall, A. G.: Oligomers formed through in-cloud methylglyoxal reactions: Chemical composition, properties, and mechanisms investigated by ultra-high resolution FT-ICR mass spectrometry, Atmos. Environ., 42, 1476-1490, doi:10.1016/j.atmosenv.2007.11.015, 2008.

Altieri, K. E., Turpin, B. J., Seitzinger, S. P., et al.: The Composition of Dissolved Organic Nitrogen in Continental Precipitation Investigated by Ultra-high Resolution FT-ICR Mass Spectrometry, Environ. Sci. Technol., in review, 2009.

Andreae, M. O., Talbot, R. W., Andreae, T. W., and Harriss, R. C.: Formic and acetic acid over the central Amazon region, Brazil 1. Dry season, J. Geophys. Res., 93, 1616-1624, 1988.

Avery, G. B., Kieber, R. J., Witt, M., and Willey, J. D.: Rainwater monocarboxylic and dicarboxylic acid concentrations in southeastern North Carolina, USA, as a function of air-mass backtrajectory, Atmos. Environ., 40, 1683-1693, 2006.

Bigelow, D. S., Dossett, S. R., and Bowersox, V. C.: Instruction Manual NADP/NTN site selection and installation, National Atmospheric Deposition Program, 2001.

Blando, J. D. and Turpin, B. J.: Secondary organic aerosol formation in cloud and fog droplets: a literature evaluation of plausibility, Atmos. Environ., 34, 1623-1632, 2000.

Claeys, M., Szmigielski, R., Kourtchev, I., Van der Veken, P., Vermeylen, R., Maenhaut, W., Jaoui, M., Kleindienst, T. E., Lewandowski, M., Offenberg, J. H., and Edney, E. O.: Hydroxydicarboxylic acids: Markers for secondary organic aerosol from the photooxidation of $\alpha$-pinene, Environ. Sci. Technol., 41, 1628-1634, 2007.

Debelius, B., Forja, J. M., Del Valls, A., and Lubián, L. M.: Effect of linear alkylbenzene sulfonate (LAS) and atrazine on marine microalgae, Mar. Pollut. Bull., 57, 559-568, 2008.

El-Zanan, H. S., Lowenthal, D. H., Zielinska, B., Chow, J. C., and Kumar, N.: Determination of the organic aerosol mass to organic carbon ratio in IMPROVE samples, Chemosphere, 60, 485-496, 2005.

Feng, J. S. and Moller, D.: Characterization of water-soluble macromolecular substances in cloud water, J. Atmos. Chem., 48, 217233, 2004.

Gao, S., Keywood, M., Ng, N. L., Surratt, J., Varutbangkul, V., Bahreini, R., Flagan, R. C., and Seinfeld, J. H.: Low-molecularweight and oligomeric components in secondary organic aerosol from the ozonolysis of cycloalkenes and alpha-pinene, J. Phys. Chem. A, 108, 10147-10164, 2004a.

Gao, S., Ng, N. L., Keywood, M., Varutbangkul, V., Bahreini, R., Nenes, A., He, J. W., Yoo, K. Y., Beauchamp, J. L., Hodyss, R. P., Flagan, R. C., and Seinfeld, J. H.: Particle phase acidity and oligomer formation in secondary organic aerosol, Environ. Sci. Technol., 38, 6582-6589, 2004b.

Gao, S., Surratt, J. D., Knipping, E. M., Edgerton, E. S., Shahgholi, M., and Seinfeld, J. H.: Characterization of polar organic components in fine aerosols in the southeastern United States: Identity, origin, and evolution, J. Geophys. Res.-Atmos., 111, D14314, doi:10.1029/2005JD006601, 2006.

Gómez-González, Y., Surratt, J.D., Cuyckens, F., Szmigielski, R., Vermeylen, R., Jaoui, M., Lewandowski, M., Offenberg, J. H., Kleindienst, T. E., Edney, E. O., Blockhuys, F., Van Alsenoy, C., Maenhaut, W., and Claeys, M.: Characterization of organosul- fates from the photooxidation of isoprene and unsaturated fatty acids in ambient aerosol using liquid chromatography/(-) electrospray ionization mass spectrometry, J. Mass Spectrom., 43, 371-382, 2008.

González-Mazo, E. and Gómez-Parra, A.: Monitoring anionic surfactants (LAS) and their intermediate degradation products in the marine environment, TrAC Trends in Anal. Chem., 15, 375-380, 1996.

González-Mazo, E., León, V. M., Sáez, M., and Gómez-Parra, A.: Occurrence and distribution of linear alkylbenzene sulfonates and sulfophenylcarboxylic acids in several Iberian littoral ecosystems, The Science of The Total Environment, 288, 215-226, 2002.

Graber, E. R. and Rudich, Y.: Atmospheric HULIS: How humiclike are they? A comprehensive and critical review, Atmos. Chem. Phys., 6, 729-753, 2006,

http://www.atmos-chem-phys.net/6/729/2006/.

Grannas, A. M., Hockaday, W. C., Hatcher, P. G., Thompson, L. G., and Mosley-Thompson, E.: New revelations on the nature of organic matter in ice cores, J. Geophys. Res.-Atmos., 111, D04304, doi:10.1029/2005jd006251, 2006.

Iinuma, Y., Muller, C., Berndt, T., Boge, O., Claeys, M., and Herrmann, H.: Evidence for the existence of organosulfates from beta-pinene ozonolysis in ambient secondary organic aerosol, Environ. Sci. Technol., 41, 6678-6683, doi:10.1021/es070938t, 2007a.

Iinuma, Y., Muller, C., Boge, O., Gnauk, T., and Herrmann, H.: The formation of organic sulfate esters in the limonene ozonolysis secondary organic aerosol (SOA) under acidic conditions, Atmos. Environ., 41, 5571-5583, doi:10.1016/j.atmosenv.2007.03.007, 2007b.

Kalberer, M., Paulsen, D., Sax, M., Steinbacher, M., Dommen, J., Prevot, A. S. H., Fisseha, R., Weingartner, E., Frankevich, V., Zenobi, R., and Baltensperger, U.: Identification of polymers as major components of atmospheric organic aerosols, Science, 303, 1659-1662, 2004.

Kawamura, K., Steinberg, S., and Kaplan, I. R.: Concentrations of monocarboxylic and dicarboxylic acids and aldehydes in southern California wet precipitations: Comparison of urban and nonurban samples and compositional changes during scavenging, Atmos. Environ., 30, 1035-1052, 1996.

Kawamura, K., Steinberg, S., Ng, L., and Kaplan, I. R.: Wet deposition of low molecular weight mono- and di-carboxylic acids, aldehydes and inorganic species in Los Angeles, Atmos. Environ., 35, 3917-3926, 2001.

Kawamura, K., Umemoto, N., Mochida, M., Bertram, T., Howell, S., and Huebert, B. J.: Water-soluble dicarboxylic acids in the tropospheric aerosols collected over east Asia and western North Pacific by ACE-Asia C-130 aircraft, J. Geophys. Res.-Atmos., 108(D23), 8639, doi:10.1029/002JD003256, 2003.

Kieber, R. J., Peake, B., Willey, J. D., and Avery, G. B.: Dissolved organic carbon and organic acids in coastal New Zealand rainwater, Atmos. Environ., 36, 3557-3563, 2002.

Kiss, G., Varga, B., Galambos, I., and Ganszky, I.: Characterization of water-soluble organic matter isolated from atmospheric fine aerosol, J. Geophys. Res.-Atmos., 107, 8339, doi:10.1029/2001JD000603, 2002.

Koch, B. P., Witt, M. R., Engbrodt, R., Dittmar, T., and Kattner, G.: Molecular formulae of marine and terrigenous dissolved organic 
matter detected by electrospray ionization Fourier transform ion cyclotron resonance mass spectrometry, Geochim. Cosmochim. Ac., 69, 3299-3308, 2005.

Krivacsy, Z., Kiss, G., Varga, B., Galambos, I., Sarvari, Z., Gelencser, A., Molnar, A., Fuzzi, S., Facchini, M. C., Zappoli, S., Andracchio, A., Alsberg, T., Hansson, H. C., and Persson, L.: Study of humic-like substances in fog and interstitial aerosol by size-exclusion chromatography and capillary electrophoresis, Atmos. Environ., 34, 4273-4281, 2000.

Lara-Martín, P. A., Gómez-Parra, A., and González-Mazo, E.: Development of a method for the simultaneous analysis of anionic and non-ionic surfactants and their carboxylated metabolites in environmental samples by mixed-mode liquid chromatographymass spectrometry, J. Chromatogr. A, 1137, 188-197, 2006.

Liggio, J., Li, S. M., and McLaren, R.: Heterogeneous reactions of glyoxal on particulate matter: Identification of acetals and sulfate esters, Environ. Sci. Technol., 39, 1532-1541, 2005.

Likens, G. E., Edgerton, E. S., and Galloway, J. N.: The composition and deposition of organic carbon in precipitation, Tellus, 35B, 16-24, 1983.

Marshall, A. G.: Fourier-Transform Ion-Cyclotron Resonance Mass-Spectrometry Retrospect and Prospects, Abstr. Pap. Am. Chem. S., 209, 78-ANYL, 1995.

Marshall, A. G.: FT-ICR mass spectrometry at high magnetic field, Abstr. Pap. Am. Chem. S., 213, 195-ANYL, 1997.

McLafferty, F. W. and Turecek, F.: Interpretation of Mass Spectra, 4 Ed., University Science Books, Mill Valley, 1-355, 1993.

Pena, R. M., Garcia, S., Herrero, C., Losada, M., Vazquez, A., and Lucas, T.: Organic acids and aldehydes in rainwater in a northwest region of Spain, Atmos. Environ., 36, 5277-5288, 2002.

Polidori, A., Turpin, B. J., Davidson, C. I., Rodenburg, L. A., and Maimone, F.: Organic PM2.5: Fractionation by polarity, FTIR spectroscopy, and OM/OC ratio for the Pittsburgh aerosol, Aerosol Sci. Technol., 42, 233-246, doi:10.1080/02786820801958767, 2008.

Raymond, P. A.: The composition and transport of organic carbon in rainfall: Insights from the natural (C-13 and C14) isotopes of carbon, Geophys. Res. Lett., 32, L14402, doi:10.1029/2005GL022879, 2005.

Reemtsma, T.: Liquid chromatography-mass spectrometry and strategies for trace-level analysis of polar organic pollutants, J. Chromatogr. A, 1000, 477-501, 2003.

Reemtsma, T., These, A., Springer, A., and Linscheid, M.: Fulvic acids as transition state of organic matter: Indications from high resolution mass spectrometry, Environ. Sci. Technol., 40, 58395845, 2006a.

Reemtsma, T., These, A., Venkatachari, P., Xia, X. Y., Hopke, P. K., Springer, A., and Linscheid, M.: Identification of fulvic acids and sulfated and nitrated analogues in atmospheric aerosol by electrospray ionization Fourier transform ion cyclotron resonance mass spectrometry, Anal. Chem., 78, 8299-8304, $2006 \mathrm{~b}$.

Romero, F. and Oehme, M.: Organosulfates - A new component of humic-like substances in atmospheric aerosols?, J. Atmos. Chem., 52, 283-294, doi:10.1007/s10874-005-0594-y, 2005.

Seitzinger, S. P. and Sanders, R. W.: Atmospheric inputs of dissolved organic nitrogen stimulate estuarine bacteria and phytoplankton, Limnol. Oceanogr., 44, 721-730, 1999.

Seitzinger, S. P., Styles, R. M., Lauck, R., and Mazurek, M. A.: Atmospheric pressure mass spectrometry: A new analytical chemi- cal characterization method for dissolved organic matter in rainwater, Environ. Sci. Technol., 37, 131-137, 2003.

Senko, M. W., Hendrickson, C. L., PasaTolic, L., Marto, J. A., White, F. M., Guan, S. H., and Marshall, A. G.: Electrospray ionization Fourier transform ion cyclotron resonance at $9.4 \mathrm{~T}$, Rapid. Commun. Mass Sp., 10, 1824-1828, 1996.

Sharp, J. H., Benner, R., Bennett, L., Carlson, C. A., Dow, R., and Fitzwater, S. E.: Re-Evaluation of High Temperature Combustion and Chemical Oxidation Measurements of Dissolved Organic Carbon in Seawater, Limnol. Oceanogr., 38, 1774-1782, 1993.

Sorooshian, A., Ng, L., Chan, A. W. H., Feingold, G., Flagan, R. C., and Seinfeld, J. H.: Particulate organic acids and overall water-soluble aerosol composition measurements from the 2006 Gulf of Mexico Atmospheric Composition and Climate Study (GoMACCS), J. Geophys. Res.-Atmos., 112, D13201, doi:10.1029/2007JD008537, 2007.

Stenson, A. C., Marshall, A. G., and Cooper, W. T.: Exact masses and chemical formulas of individual Suwannee River fulvic acids from ultrahigh resolution electrospray ionization Fourier transform ion cyclotron resonance mass spectra, Anal. Chem., 75, 1275-1284, 2003.

Surratt, J. D., Kroll, J. H., Kleindienst, T. E., Edney, E. O., Claeys, M., Sorooshian, A., Ng, N. L., Offenberg, J. H., Lewandowski, M., Jaoui, M., Flagan, R. C., and Seinfeld, J. H.: Evidence for organosulfates in secondary organic aerosol, Environ. Sci. Technol., 41, 517-527, 2007.

Surratt, J. D., Gómez-González, Y., Chan, A. W. H., Vermeylen, R., Shahgholi, M., Kleindienst, T. E., Edney, E. O., Offenberg, J. H., Lewandowski, M., Jaoui, M., Maenhaut, W., Claeys, M., Flagan, R. C., and Seinfeld, J. H.: Organosulfate Formation in Biogenic Secondary Organic Aerosol, J. Phys. Chem. A, 112, 8345-8378, 2008.

Tolocka, M. P., Myoseon, J., Joy, M. G., Frederick, J. C., Richard, M. K., and Murray, V. J.: Formation of oligomers in secondary organic aerosol, Environ. Sci. Technol., 38, 1428-1434, 2004.

Willey, J. D., Kieber, R. J., Eyman, M. S., and Avery, G. B.: Rainwater dissolved organic carbon: Concentrations and global flux, Global Biogeochem. Cy., 14, 139-148, 2000.

Wozniak, A. S., Bauer, J. E., Sleighter, R. L., Dickhut, R. M., and Hatcher, P. G.: Technical Note: Molecular characterization of aerosol-derived water soluble organic carbon using ultrahigh resolution electrospray ionization Fourier transform ion cyclotron resonance mass spectrometry, Atmos. Chem. Phys., 8, 50995111, 2008, http://www.atmos-chem-phys.net/8/5099/2008/.

Wu, Z. G., Rodgers, R. P., and Marshall, A. G.: Two- and threedimensional van Krevelen diagrams: A graphical analysis complementary to the Kendrick mass plot for sorting elemental compositions of complex organic mixtures based on ultrahighresolution broadband Fourier transform ion cyclotron resonance mass measurements, Anal. Chem., 76, 2511-2516, 2004.

Zappoli, S., Andracchio, A., Fuzzi, S., Facchini, M. C., Gelencser, A., Kiss, G., Krivacsy, Z., Molnar, A., Meszaros, E., Hansson, H. C., Rosman, K., and Zebuhr, Y.: Inorganic, organic and macromolecular components of fine aerosol in different areas of Europe in relation to their water solubility, Atmos. Environ., 33, 27332743, 1999. 